\title{
Growth hormone and prolactin response to bromocriptine in patients with Huntington's chorea
}

\author{
R. J . C H A L M E R , R. H . J O H N S O N, H . J K E O G H, \\ A N D R. N. N A N D A \\ From Glasgow University Department of Neurology, Institute of Neurological Sciences, \\ Southern General Hospital, Glasgow
}

SUMMARY The growth hormone (hGH) and prolactin (hPRL) responses to oral bromocriptine were studied in two groups of patients with Huntington's chorea and in seven healthy control subjects. The patients included six patients who had previously been treated with phenothiazines and six patients who had not received phenothiazine treatment. All medication was stopped 72 hours before the investigation which involved taking blood samples for up to 210 minutes after taking bromocriptine $(2.5 \mathrm{mg})$. Plasma samples were analysed for hGH and hPRL. There was no significant difference in basal hGH concentrations between the patients and control subjects. The $\mathrm{hGH}$ response to bromocriptine varied in the individual patients but the concentrations were significantly lower in the patients compared with the controls between 160 and 210 minutes. The basal concentrations of hPRL were also not different, apart from the findings of elevated hPRL concentrations in three patients previously treated with phenothiazines. The patients and control subjects showed a consistent fall in hPRL concentrations after taking bromocriptine. The lower peak hGH response to bromocriptine found in the patients suggests that there may be an alteration of dopaminergic neurones mediating $\mathrm{hGH}$ release.

Huntington's chorea is an inherited degenerative disorder of the nervous system. There is evidence of biochemical abnormalities in patients with the disorder. This includes the finding of low levels of $\gamma$ aminobutyric acid (GABA) and its synthesising enzyme (glutamic acid decarboxylase). Dopamine levels are normal but dopamine receptor activity may be disturbed (Barbeau, 1973; Perry et al., 1973; Bird and Iversen, 1974; Stahl and Swanson, 1974; Bird et al., 1976). Patients with Huntington's chorea often show weight loss and excessive sweating (Bruyn, 1968), and this may be related to altered hypothalamic function. It has recently been reported that the growth hormone (hGH) response to insulin induced hypoglycaemia in patients with the disorder showed an earlier elevation than controls (Keogh et al., 1976; Phillipson and Bird, 1976), and it was suggested that this may be due to increased sensitivity of dopamine receptors in the hypothalamus mediating hGH release.

Address for reprint requests: R. J. Chalmers, Lecturer in Nutrition, The Queen's College, Glasgow, 2 Park Drive, Glasgow, Scotland. Accepted 29 August 1977
Bromocriptine is a specific dopamine receptor agonist which produces an elevation of hGH and depresses prolactin (hPRL) concentrations in normal subjects (del Pozo et al., 1972; Cammani et al., 1976). We, therefore, decided to investigate the hGH response to bromocriptine in patients with Huntington's chorea to determine if there was any evidence for altered sensitivity of dopamine receptors mediating hGH release.

\section{Subjects and methods}

Twelve unrelated patients with chorea and a positive family history of Huntington's chorea were studied. The first group were inpatients in Hartwood Hospital, Lanarkshire under the care of Dr J. Bolt. They were all receiving a variety of drugs including phenothiazines. Six patients, two males and four females aged 43-53 years (mean 47 years), were studied. The second group consisted of five outpatients and one inpatient from Hartwood Hospital who had not received treatment with phenothiazines. The six patients comprised two males and four females aged 47-68 years (mean 59 years). Seven healthy control 
subjects, four males and three females aged 2355 years (mean 44 years), were also siudied. Consent was ob:ained after the purpose and procedure had been explained to the patients and their relatives. The control subjects all agreed to take part in the investigation.

Drug medication was stopped 72 hours before the investigation which was carried out in the morning after an overnight fast. The half life of hGH is relatively short $(20-30 \mathrm{~min})$, and we, therefore, decided to take blood samples at $10 \mathrm{~min}$ intervals during the period of the hGH response. Blood samples $(10 \mathrm{ml})$ were taken from a cannula in an antecubital vein before and at $30,60,90$, $120,130,140,150,160,170,180$, and 210 minutes after an oral dose of bromocriptine $(2.5 \mathrm{mg})$. Blood samples were collected in heparinised tubes for later separation of plasma. The plasma samples were analysed by a radioimmunoassay technique (Sorin, Gruppo Radiochimica, Italy) for hGH (Morgan, 1966) and hPRL (Reuter et al., 1976). The growth hormone concentrations are expressed in terms of the World Health Organisation First International Reference Preparation of Growth Hormone, $66 / 2171 \mathrm{mg}=2 \mathrm{IU}$. The radioimmunoassay kits were supplied by Eurotope Laboratory Services, London. Significance of difference was examined with the Mann-Whitney nonparametric $\mathrm{U}$ test for small samples (Mann and Whitney, 1947).

\section{Results}

Details of the recent medication for the six inpatients who had received phenothiazines before the investigation is given in Table 1 .

PLASMA GROWTH HORMONE (hGH) (TABLE 2)

Patients treated with phenothiazines There was no significant difference between the basal hGH concentrations of the patients and controls before

Table 1 Details of six patients with Huntington's chorea and medication received during treatment

\begin{tabular}{|c|c|c|c|}
\hline Patient & Sex & Age (yr) & Medication \\
\hline DG & $\mathbf{M}$ & 53 & $\begin{array}{l}\text { Chlorpromazine } \\
\text { Benzhexol }\end{array}$ \\
\hline MN & $\mathbf{M}$ & 43 & $\begin{array}{l}\text { Chlorpromazine } \\
\text { Orphenadrine }\end{array}$ \\
\hline AR & $\mathbf{F}$ & 47 & $\begin{array}{l}\text { Trifluoperazine } \\
\text { Thioridazine }\end{array}$ \\
\hline AMcL & $\mathbf{F}$ & 45 & $\begin{array}{l}\text { Diazepam, Fluphenazine } \\
\text { Benzhexol, Nitrazepam }\end{array}$ \\
\hline AMcK & $\mathbf{M}$ & 44 & $\begin{array}{l}\text { Trifluoperazine, Codeine } \\
\text { Dichloralphenazone }\end{array}$ \\
\hline MB & $\mathbf{F}$ & 48 & $\begin{array}{l}\text { Chlorpromazine } \\
\text { Thiopropazate }\end{array}$ \\
\hline
\end{tabular}

taking bromocriptine. All the controls showed an increase in hGH concentrations after bromocriptine but the response of the patients was significantly lower than the controls at 160,170, 180 , and 210 minutes. Four of the patients showed an increase in hGH concentrations after bromocriptine but only three showed a peak hGH response greater than $10 \mathrm{mu} / 1$ and the remaining two patients failed to show a response.

Patients not treated with phenothiazines There was no significant difference in the resting hGH concentrations before bromocriptine between the patients and controls. Only three of the patients showed a rise in hGH concentrations after taking bromocriptine and only one had a peak greater than $10 \mathrm{mu} / \mathrm{l}$. The hGH concentrations of the patients were significantly lower than the corresponding values for the controls at 150, 160, 170, 180 , and 210 minutes.

PLASMA PROLACTIN (hPRL) (TABLE 3)

Patients treated with phenothiazines Basal hPRL concentrations were markedly elevated $(>1000 \mathrm{mu} / \mathrm{l})$ in the two patients who failed to show an hGH response and raised $(900 \mathrm{mu} / \mathrm{l})$ in another patient. Basal hPRL concentrations in the remaining four patients were within the range of the corresponding values for the controls (60-440 mu/1). Both the patients and the control subjects showed a consistent fall from basal hPRL concentrations after bromocriptine.

Patients not treated with phenothiazines There was no significant difference in hPRL concentrations between patients and controls either before or after taking bromocriptine. Four of the five patients showed a consistent fall from resting hPRL concentrations after taking bromocriptine.

\section{Discussion}

Biochemical assay of corpus striatum obtained post mortem from patients who have suffered from Huntington's chorea shows a reduction of GABA and glutamic acid decarboxylase-the enzyme which synthesises GABA-and normal levels of dopamine (Perry et al., 1973; Bird and Iversen, 1974; Stahl and Swanson, 1974). There is evidence for a relationship between GABA and dopamine-releasing neurones as elevation of brain GABA levels by inhibition of GABA transaminase alters dopamine turnover (Shoulson et al., 1976). The development of the hyperkinetic condition characteristic of the disorder may be related to a change in the interrelationship between dopamine and GABA-containing neurones. Although dopamine levels are normal, dopamine receptors may 
Table 2 Plasma growth hormone concentration in milli-units/l $(\mathrm{mu} / \mathrm{l})$ before and after the administration of bromocriptine $(2.5 \mathrm{mg})$ in 12 patients with Huntington's chorea (six receiving and six not receiving phenothiazines) and in seven normal control subjects

\begin{tabular}{|c|c|c|c|c|c|c|c|c|c|c|c|c|c|}
\hline $\begin{array}{l}\text { Patient } \\
\text { numbers }\end{array}$ & $\begin{array}{l}\text { Time } \\
\text { (min) }\end{array}$ & 0 & 30 & 60 & 90 & 120 & 130 & 140 & 150 & 160 & 170 & 180 & 210 \\
\hline \multicolumn{14}{|l|}{$\begin{array}{l}\text { Treated with } \\
\text { phenothiazine }\end{array}$} \\
\hline 016665 & & 2.0 & 3.0 & 3.0 & 2.8 & 4.0 & 4.0 & 7.0 & 10.0 & $15.0^{*}$ & - & - & - \\
\hline 012367 & & 1.6 & 2.4 & 1.4 & 1.2 & 2.6 & 4.8 & 4.2 & 3.8 & 3.8 & 6.0 & 6.0 & 6.2 \\
\hline 016867 & & 16.4 & 10.0 & 4.8 & 9.6 & 10.6 & 20.4 & 27.0 & 24.4 & 13.4 & 12.0 & 12.0 & 7.8 \\
\hline 011267 & & 1.6 & 1.4 & 1.0 & 1.4 & 1.0 & 0.4 & 0.6 & 1.0 & 1.4 & 2.8 & 2.6 & 3.2 \\
\hline 016389 & & 1.0 & 1.0 & 0.6 & 0.4 & 3.8 & 7.8 & 10.0 & 12.8 & 10.4 & 9.0 & 6.6 & 4.0 \\
\hline \multirow[t]{3}{*}{011377} & & 2.4 & 1.2 & 1.0 & 1.0 & 0.8 & 0.8 & 1.2 & 0.8 & 2.0 & 1.4 & 3.6 & 1.6 \\
\hline & Mean & 4.2 & 3.2 & 2.0 & 2.7 & 3.8 & 6.4 & 8.3 & 8.8 & 7.7 & 6.2 & 6.2 & 4.6 \\
\hline & SEM $=$ & 2.5 & 1.4 & 0.7 & 1.4 & 1.5 & 3.0 & 4.0 & 3.7 & 2.5 & 2.0 & 1.6 & 1.1 \\
\hline \multicolumn{14}{|l|}{$\begin{array}{l}\text { Not treated with } \\
\text { phenothiazine }\end{array}$} \\
\hline 013511 & & 1.2 & 0.6 & 0.4 & 0.4 & 14.0 & 14.0 & 14.0 & 1.2 & 10.4 & 4.2 & 6.6 & 8.0 \\
\hline 808794 & & 1.8 & 0.8 & 0.8 & 4.0 & 2.6 & 2.4 & 1.8 & 1.4 & 1.2 & 1.0 & 1.0 & 0.8 \\
\hline 806513 & & 6.2 & 2.8 & 3.6 & 6.8 & 5.2 & 7.4 & 6.4 & 7.4 & 9.0 & 5.0 & 5.8 & 7.0 \\
\hline 227498 & & 7.0 & 3.4 & 3.4 & 3.0 & 3.4 & 2.6 & 2.4 & 2.4 & 2.4 & 2.6 & 3.2 & 3.2 \\
\hline 244298 & & 0.4 & 0.2 & 0.6 & 3.0 & 7.0 & 6.2 & 4.0 & 2.4 & 2.4 & 2.2 & 2.2 & 2.2 \\
\hline \multirow[t]{3}{*}{823307} & & 1.0 & 1.2 & 0.6 & 0.6 & 7.0 & 9.0 & 7.4 & 5.2 & 5.4 & 6.0 & 3.4 & 4.4 \\
\hline & Mean & 2.9 & 1.5 & 1.6 & 3.0 & 6.5 & 6.9 & 6.0 & 3.3 & 5.1 & 3.5 & 3.7 & 4.3 \\
\hline & $\mathbf{S E M} \pm$ & 1.2 & 0.5 & 0.6 & 1.0 & 1.7 & 1.8 & 1.8 & 1.0 & 1.6 & 0.8 & 0.9 & 1.1 \\
\hline Control subjects & Mean & 6.1 & 6.6 & 4.7 & 4.4 & 7.7 & 9.5 & 12.0 & 14.0 & 15.2 & 17.4 & 15.1 & 12.1 \\
\hline & $\mathrm{SEM}=$ & 3.0 & 3.2 & 1.8 & 2.7 & 3.0 & 3.7 & 3.4 & 3.1 & 2.7 & 2.1 & 2.4 & 4.9 \\
\hline \multirow{2}{*}{$\begin{array}{l}\text { Significance of } \\
\text { difference between } \\
\text { patients and } \\
\text { control subjects }\end{array}$} & $\begin{array}{l}\text { Treated with } \\
\text { phenothiazine }\end{array}$ & NS & NS & NS & NS & NS & NS & NS & NS & $\mathrm{P}<0.05$ & $\mathrm{P}<0.005$ & $P<0.01$ & $P<0.05$ \\
\hline & $\begin{array}{l}\text { Not treated } \\
\text { with } \\
\text { phenothiazine }\end{array}$ & NS & NS & NS & NS & NS & NS & NS & $P<0.01$ & $P<0.01$ & $P<0.002$ & $\mathrm{P}<0.002$ & $P<0.05$ \\
\hline
\end{tabular}

*Investigation discontinued after 160 minutes.

be hypersensitive (Barbeau, 1961, 1973; Bird et al., 1976). If there is hypersensitivity of dopamine receptors, we might expect to find increased responsiveness of dopamine receptors mediating hGH release, and this might be the basis for the earlier release of hGH reported in Huntington's chorea (Keogh et al., 1976; Phillipson and Bird, 1976).

We did not find any significant elevation of basal hGH levels in our patients as has been reported by Phillipson and Bird (1976). The control subjects all showed a rise in hGH concentrations after taking bromocriptine and our results are consistent with other published findings (Tolis $e t$ al., 1975; Cammani et al., 1976). In the patients with Huntington's chorea the majority showed a reduced hGH response compared with controls. However, Parkes et al. (1976) failed to find an hGH response to $2.5 \mathrm{mg}$ of bromocriptine in patients with Parkinson's disease although they did find a response to higher doses. It is possible that the dose of bromocriptine used in our study was too low but we were unwilling to increase the dose as higher doses are known to increase chorea (Kartzinel, 1976). We do not know if the lower peak hGH response to bromocriptine found in patients with Huntington's chorea is due to an alteration of growth hormone release mechanisms. The finding of a lower peak hGH response to bromocriptine in our patients suggests that the earlier hGH response reported to follow insulininduced hypoglycaemia in patients with the disorder is not due to increased sensitivity of dopamine receptors mediating hGH release.

In the investigation of patients who had previously received phenothiazines the failure to detect a consistent hGH response may have been because only 72 hours had been allowed between withdrawal of drug treatment and the investigation. Phenothiazines are known to block dopamine receptors (Anden et al., 1964), to impair hGH responses (Sherman et al., 1971), and to increase hPRL concentrations (Beumont et al., 1974; Meltzer et al., 1976), and this may explain why the two patients with the greatest increase in basal hPRL concentrations failed to show an hGH response. Klawans (1970) has proposed that dopamine receptor hypersensitivity may follow withdrawal of phenothiazine treatment but there was no evidence of a hypersensitive hGH response 
Table 3 Plasma prolactin concentrations in mu/l before and after the administration of bromocriptine $(2.5 \mathrm{mg})$ in 12 patients with Huntington's chorea (six receiving and six not receiving phenothiazines) and in seven normal control subjects

\begin{tabular}{|c|c|c|c|c|c|c|c|c|c|c|c|c|c|}
\hline $\begin{array}{l}\text { Patient } \\
\text { numbers }\end{array}$ & $\begin{array}{l}\text { Time } \\
(\min )\end{array}$ & 0 & 30 & 60 & 90 & 120 & 130 & 140 & 150 & 160 & 170 & 180 & 210 \\
\hline \multirow[t]{2}{*}{$\begin{array}{l}\text { Treated w } \\
\text { phenothia } \\
016665 \\
012367 \\
016867 \\
011267 \\
016389 \\
011377\end{array}$} & & $\begin{array}{r}900 \\
280 \\
180 \\
1800 \\
60 \\
1020\end{array}$ & $\begin{array}{r}840 \\
230 \\
200 \\
1800 \\
80 \\
820\end{array}$ & $\begin{array}{r}770 \\
280 \\
70 \\
1800 \\
80 \\
640\end{array}$ & $\begin{array}{r}650 \\
220 \\
36 \\
1640 \\
40 \\
760\end{array}$ & $\begin{array}{r}440 \\
220 \\
40 \\
1580 \\
40 \\
600\end{array}$ & $\begin{array}{r}600 \\
160 \\
60 \\
1380 \\
40 \\
400\end{array}$ & $\begin{array}{r}240 \\
160 \\
80 \\
1240 \\
60 \\
420\end{array}$ & $\begin{array}{r}300 \\
100 \\
80 \\
1160 \\
20 \\
500\end{array}$ & $\begin{array}{r}280^{*} \\
100 \\
60 \\
1240 \\
60 \\
400\end{array}$ & $\begin{array}{r}- \\
70 \\
40 \\
1000 \\
80 \\
370\end{array}$ & $\begin{array}{r}- \\
70 \\
40 \\
1000 \\
80 \\
320\end{array}$ & $\begin{array}{r}- \\
120 \\
40 \\
1000 \\
80 \\
260\end{array}$ \\
\hline & $\begin{array}{l}\text { Mean } \\
\text { SEM } 1 \text { : }\end{array}$ & $\begin{array}{l}707 \\
271\end{array}$ & $\begin{array}{l}662 \\
264\end{array}$ & $\begin{array}{l}607 \\
266\end{array}$ & $\begin{array}{l}558 \\
250\end{array}$ & $\begin{array}{l}487 \\
237\end{array}$ & $\begin{array}{l}440 \\
208\end{array}$ & $\begin{array}{l}367 \\
183\end{array}$ & $\begin{array}{l}360 \\
176\end{array}$ & $\begin{array}{l}357 \\
185\end{array}$ & $\begin{array}{l}312 \\
182\end{array}$ & $\begin{array}{l}302 \\
406\end{array}$ & $\begin{array}{l}300 \\
179\end{array}$ \\
\hline \multirow[t]{2}{*}{$\begin{array}{l}\text { Not treated with } \\
\text { phenothiazine } \\
013511 \\
808794 \\
806513 \\
227498 \\
244298 \\
823307\end{array}$} & & $\begin{array}{l}310 \\
220 \\
220 \\
240 \\
200 \\
360\end{array}$ & $\begin{array}{l}180 \\
160 \\
200 \\
200 \\
200 \\
320\end{array}$ & $\begin{array}{l}200 \\
120 \\
200 \\
160 \\
120 \\
260\end{array}$ & $\begin{array}{l}160 \\
140 \\
180 \\
120 \\
200 \\
200\end{array}$ & $\begin{array}{l}310 \\
140 \\
180 \\
120 \\
380 \\
200\end{array}$ & $\begin{array}{l}310 \\
120 \\
160 \\
160 \\
340 \\
180\end{array}$ & $\begin{array}{l}310 \\
100 \\
160 \\
120 \\
320 \\
180\end{array}$ & $\begin{array}{l}260 \\
140 \\
180 \\
120 \\
240 \\
180\end{array}$ & $\begin{array}{l}180 \\
100 \\
160 \\
120 \\
260 \\
160\end{array}$ & $\begin{array}{l}200 \\
140 \\
160 \\
160 \\
260 \\
160\end{array}$ & $\begin{array}{r}200 \\
80 \\
160 \\
100 \\
240 \\
180\end{array}$ & $\begin{array}{l}170 \\
100 \\
120 \\
100 \\
200 \\
160\end{array}$ \\
\hline & $\begin{array}{l}\text { Mean } \\
\text { SEM }+\end{array}$ & $\begin{array}{r}242 \\
35\end{array}$ & $\begin{array}{r}210 \\
23\end{array}$ & $\begin{array}{r}177 \\
22\end{array}$ & $\begin{array}{r}167 \\
13\end{array}$ & $\begin{array}{r}222 \\
42\end{array}$ & $\begin{array}{r}212 \\
37\end{array}$ & $\begin{array}{r}198 \\
39\end{array}$ & $\begin{array}{r}187 \\
22\end{array}$ & $\begin{array}{r}163 \\
23\end{array}$ & $\begin{array}{r}180 \\
18\end{array}$ & $\begin{array}{r}160 \\
25\end{array}$ & $\begin{array}{r}142 \\
17\end{array}$ \\
\hline $\begin{array}{l}\text { Control } \\
\text { subjects }\end{array}$ & $\begin{array}{l}\text { Mean } \\
\text { SEM } \pm\end{array}$ & $\begin{array}{r}184 \\
48\end{array}$ & $\begin{array}{r}161 \\
38\end{array}$ & $\begin{array}{r}161 \\
46\end{array}$ & $\begin{array}{r}142 \\
37\end{array}$ & $\begin{array}{r}140 \\
40\end{array}$ & $\begin{array}{r}120 \\
32\end{array}$ & $\begin{array}{r}121 \\
34\end{array}$ & $\begin{array}{r}168 \\
60\end{array}$ & $\begin{array}{r}140 \\
53\end{array}$ & $\begin{array}{r}145 \\
49\end{array}$ & $\begin{array}{r}141 \\
49\end{array}$ & $\begin{array}{r}142 \\
40\end{array}$ \\
\hline \multirow{2}{*}{$\begin{array}{l}\text { Significance of } \\
\text { difference } \\
\text { between } \\
\text { patients and } \\
\text { control subjects }\end{array}$} & $\begin{array}{l}\text { Treated with } \\
\text { phenothiazine }\end{array}$ & NS & NS & NS & NS & NS & NS & NS & NS & NS & NS & NS & NS \\
\hline & $\begin{array}{l}\text { Not treated } \\
\text { with } \\
\text { phenothiazine }\end{array}$ & NS & NS & NS & NS & NS & NS & NS & NS & NS & NS & NS & NS \\
\hline
\end{tabular}

*Investigation discontinued after 160 minutes.

after withdrawal of phenothiazine treatment in our study. In the investigation on patients who had not received phenothiazines most of the patients showed a depression of hPRL concentrations after taking bromocriptine.

The results presented here demonstrate that the hGH response to bromocriptine is significantly reduced in patients with Huntington's chorea and suggest that there may be an alteration of dopaminergic neurones mediating hGH release. The lower peak hGH response may be related to decreased sensitivity of dopamine receptors or to reduced levels of dopamine at the postsynaptic receptor as the action of bromocriptine is dependent on intact catecholamine synthesis and storage mechanisms (Johnson et al., 1976). These suggestions merit further investigation as neuroendocrine studies may give useful information about hypothalamic neurone function in Huntington's chorea.

We wish to thank the patients and subjects for their co-operation and the Secretary of State for Scotland for financial support. We also wish to thank Dr Jean Bolt, some of whose patients were included in our study.

\section{References}

Anden. N. E., Roos, B. E., and Werdinius, B. (1964). Effects of chlorpromazine, haloperidol and reserpine on the levels of phenolic acids in rabbit corpus striatum. Life Sciences, 3, 149-158.

Barbeau, A. (1961). Dopamine and basal ganglia diseases. Archives of Neurology (Chicago), 4, 97102.

Barbeau, A. (1973). Biochemistry of Huntington's chorea. In Advances in Neurology, Vol. 1, pp. 473-516. Edited by A. Barbeau, T. N. Chase, and G. W. Paulson. Raven Press: New York.

Beumont, P. J. V., Gelder, M. G., and Friesen, H. G. (1974). The effects of phenothiazines on endocrine function. 1. Patients with inappropriate lactation and amenorrhoea. British Journal of Psychiatry, 124, 413-419.

Bird, E. D., and Iversen, L. L. (1974). Huntington's chorea : post mortem measurement of glutamic acid decarboxylase, choline acetyltransferase and dopamine in basal ganglia. Brain, 97, 457-472.

Bird, E. D., Chiappa, S. A., and Fink, G. (1976). Brain 
immunoreactive gonadotropin-releasing hormone in Huntington's chorea and in non-choreic subjects. Nature, 260, 536-538.

Bruyn, G. W. (1968). Huntington's chorea, history, clinical and laboratory synopsis. In Handbook of Clinical Neurology, Vol. 6, pp. 298-387. Edited by P. J. Vinken and G. W. Bruyn. North Holland: Amsterdam.

Cammani, F., Massara, F., Belforte, L.. and Molinatti, G. M. (1975). Changes in plasma growth hormone levels in normal and acromegalic subjects following administration of 2-bromo-alpha-ergocryptine. Journal of Clinical Endocrinology and Metabolism, 40, 363-366.

Johnson, A. M., Loew. D. M., and Vigouret, J. M. (1976). Stimulant properties of bromocriptine on central dopamine receptors in comparison to apomorphine, (+)-amphetamine and L-dopa. British Journal of Pharmacology, 56, 59-68.

Kartzinel, R., Hunt, R. D., and Calne, D. B. (1976). Bromocriptine in Huntington's chorea. Archives of Neurology (Chicago), 33, 517-518.

Keogh, H. J., Johnson, R. H., Nanda, R. N., and Sulaiman W. R. (1976). Altered growth hormone release in Huntington's chorea. Journal of Neurology, Neurosurgery, and Psychiatry, 39, 244-248.

Klawans, H. L. (1970). A pharmacologic analysis of Huntington's chorea. European Neurology, 4, 148163.

Mann, H. B., and Whitney, D. R. (1947). On a test of whether one or two random variables is stochastically larger than the other. Annals of Mathematical Statistics, 18, 52-54.

Meltzer, H. Y., Victor, M. D., and Fang, S. (1976). The effect of neuroleptics on serum prolactin in schizophrenic patients. Archives of General Psychiatry, 33, 279-286.

Morgan, C. R. (1966). Human growth hormone immunoassay: two antibody methods using ${ }^{125} \mathrm{I}$ tracer.
Proceedings of the Society for Experimental Biology and Medicine, 121, 62-81.

Parkes, J. D., Marsden, C. D., Donaldson, I., GaleaDebona, A., Walters, J., Kennedy, G., and Asselman, P. (1976). Bromocriptine treatment in Parkinson's disease. Journal of Neurology, Neurosurgery, and Psychiatry, 39, 184-193.

Perry, T. L., Hansen, S., and Kloster, M. (1973). Huntington's chorea: deficiency of $\gamma$ aminobutyric acid in brain. New England Journal of Medicine, 288, 337-342.

Phillipson, O. T., and Bird, E. D. (1976). Plasma growth hormone concentrations in Huntington's chorea. Clinical Science, 50, 551-554.

del Pozo, E., Brun del Re, R., Varga, L. and Friesen, H. G. (1972). The inhibition of prolactin secretion in man by CB-154. Journal of Clinical Endocrinology and Metabolism, 35, 768-771.

Reuter, A. M., Kennes, F., Gevaert, Y., and Franchimont, P. (1976). Homologous radio immunoassay for human prolactin. International Journal of Nuclear Medicine and Biology, 3, 21-28.

Sherman, L., Kein, S., and Benjamin, F. (1971). Effect of chlorpromazine on serum growth hormone concentrations in man. New England Journal of Medicine, 284, 72-74.

Shoulson, I., Kartzinel, R., and Chase, T. N. (1976). Huntington's disease: treatment with dipropylacetic acid and gamma-aminobutyric acid. Neurology (Minneapolis), 26, 61-63.

Stahl, W. L., and Swanson, P. D. (1974). Biochemical abnormalities in Huntington's chorea brains. Neurology (Minneapolis), 24, 813-819.

Tolis, G., Pinter, E. J., and Friesen, H. G. (1975). The acute effect of 2-bromo- $\alpha$-ergocriptine (CB-154) on anterior pituitary hormones and free fatty acids in man. International Journal of Clinical Pharmacology, 12, 281-283. 